\begin{tabular}{|c|c|c|c|c|}
\hline & $\begin{array}{l}\text { Post offices in } \\
\text { deprived wards } \\
(\mathrm{n}=16)\end{array}$ & $\begin{array}{c}\text { Post offices in } \\
\text { other wards } \\
(n=70)\end{array}$ & $\begin{array}{l}\gamma \text { with Yates's } \\
\text { correction; } \\
\quad \mathrm{df}=1\end{array}$ & $\mathrm{p}$ Value \\
\hline No $(\%)$ carrying adverts & $11(68 \cdot 8)$ & $29(41 \cdot 4)$ & $2 \cdot 9$ & 0.089 \\
\hline $\begin{array}{l}\text { or more sites } \\
\text { No (\%) with area of adverts }\end{array}$ & $5(31 \cdot 2)$ & $15(21 \cdot 4)$ & $0 \cdot 3$ & 0.61 \\
\hline$\geqslant 1 \mathrm{~m}^{2}$ & $8(50 \cdot 0)$ & $17(24 \cdot 3)$ & $3 \cdot 0$ & 0.08 \\
\hline
\end{tabular}

to decrease the total number of external permanent advertising signs on shopfronts over the next five years, but the agreement makes no reference to the total area of advertising or the proportion of shops carrying advertising. Such a vague agreement has very little chance of being closely monitored and even less of being effective.

The Health of the Nation suggests a target for the reduction of the prevalence of cigarette smoking in men and women to $22 \%$ and $21 \%$ respectively by the year $2000 .^{+}$Evidence from New Zealand shows that a ban in tobacco advertising was associated with an immediate drop in both smoking prevalence and total consumption of cigarettes, 'yet despite this the British government is currently not supporting the proposed European Community Directive on a complete ban on tobacco advertising. Surely the time has come for the government to acknowledge the problems inherent in monitoring the voluntary agreement, recognise the strength of the new evidence on the effectiveness of tobacco advertising bans, and reconsider its position on this important public health issue.

\title{
Comment
}

Tobacco advertising is widespread in Bristol, $30 \%$ of post offices carrying $1 \mathrm{~m}^{2}$ or more of tobacco advertising. There seems to be a suggestion of more advertising in relatively deprived areas, findings which are similar to that of a study of billboard advertising in the Newcastle Metro. Tobacco advertising in the United Kingdom is controlled by a voluntary agreement with the tobacco industry. 'There has been recent agreement

We thank Miss S Lansbury, who visited and photographed all the post offices.

1 Voluntary agreement on tobacco products; advertising and promotion and health warnings. London: Department of Health, 1992.

Jarman B. Identification of underprivileged areas. BMF 1983; 286: 1705-8.

3 Matthews P. Medicine and the media. BMF 1986;293:442.

4 Secretary of State for Health. The health of the nution. London: HMSO, 1991.

5 Tobacco advertising bans work. London: Action on Smoking and Health, 1991

(Accepted 27 April 1992)

\section{Treatment of amiodarone induced thyrotoxicosis with carbimazole alone and continuation of amiodarone}

\author{
Peter H Davies, Jayne A Franklyn, \\ Michael C Sheppard
}

Department of Medicine, University of Birmingham, Queen Elizabeth Hospital, Birmingham B15 2TH

Peter H Davies, senior house officer

Jayne A Franklyn, senior lecturer

Michael C Sheppard, professor

Correspondence to:

Dr Franklyn.

BMF 1992;305:224-5
The antiarrhythmic drug amiodarone contains $37 \%$ iodine and is recognised to cause abnormal results of thyroid function tests in euthyroid patients as well as overt thyrotoxicosis or hypothyroidism in up to $10 \%$ of patients given the drug long term.' Withdrawal is recommended when the drug has induced thyrotoxicosis but is often inappropriate because of the underlying cardiovascular problem. The elimination half life of the drug, 90 days, determines that any response to withdrawal is slow. In addition, thyroidal iodine uptake is suppressed during treatment and after withdrawal' so that radioactive iodine treatment is ineffective. Thyroidectomy under local or general anaesthesia is an alternative $e^{2}$ but may be hazardous in patients with cardiovascular disease.

Drug treatment is preferable to surgery in those with amiodarone induced thyrotoxicosis but treatment with thionamides alone has been found ineffective, ${ }^{13}$ especially in patients continuing amiodarone. Successful combination treatment with methimazole or propylthiouracil and potassium perchlorate has been reported in patients stopping amiodarone, ${ }^{4}$ as well as successful combination treatment with antithyroid drugs and high dose steroids, ${ }^{;}$although adding potassium perchlorate or steroids has been found unhelpful by other researchers. None of these regimens are without hazard because of serious potential side effects of potassium perchlorate and prednisolone.
In view of these problems of treating amiodarone induced thyrotoxicosis we have explored other options. We describe treatment with carbimazole alone in five consecutive patients presenting with thyrotoxicosis and continuing amiodarone treatment.

\section{Patients, methods, and results}

Amiodarone induced thyrotoxicosis was diagnosed in each patient (all men; mean age 56.4 (range 31-72) years) from clinical features and circulating thyroxine, triiodothyronine, and thyrotrophin. Amiodarone (mean dose 180 (range 100-200) mg/day; mean treatment duration 27 (14-18) months) had been prescribed for resistant recurrent arrhythmias associated with ischaemic heart disease in four patients (two with supraventricular tachycardia and two ventricular tachycardia) and associated with the Wolff-ParkinsonWhite syndrome in one. Presenting features included weight loss (in all patients), tremor (two), increased sweating (two), fatigue (two), and worsening angina (two). No patient had a history of thyroid disease. A nodular goitre was present in one and none had ophthalmopathy other than lid lag. Concentrations of thyroxine and triiodothyronine were raised in all (free thyroxine, mean 70 (range $51 \cdot 0-120$ ) pmol/l, (normal range $9-24 \mathrm{pmol} / \mathrm{l})$; free triiodothyronine, mean $13 \cdot 0$ (range $9 \cdot 7->20$ ) pmol $/ 1$, (normal range $3.9 \mathrm{pmol} / \mathrm{l}$ ) and thyrotrophin was suppressed to $<0.5 \mathrm{mU} / \mathrm{l}$. Thyroid autoantibodies were weakly positive in one patient (antimicrosomal titre 1:400, antithyroglobulin $1: 80$ ).

After amiodarone induced thyrotoxicosis had been diagnosed, treatment with carbimazole was started (starting dose $20-60 \mathrm{mg} /$ day, mean dose $37 \mathrm{mg} /$ day). Patients were biochemically euthyroid (had normal concentrations of free thyroxine and free triiodothyronine) after 3-16 (mean 8.6) weeks of carbimazole treatment and were clinically euthyroid after a mean of 14 weeks' treatment. Carbimazole doses were titrated 
against free thyroxine, free triiodothyronine, and thyrotrophin, and treatment was continued for 12-15 months. One patient became hypothyroid while taking carbimazole and remained hypothyroid after drug withdrawal. He remained well on long term thyroxine replacement. Three further patients remained well and euthyroid 6-18 months after withdrawal of carbimazole. One patient's thyrotoxicosis relapsed 12 months after carbimazole was stopped; he was treated for a further 15 months and was euthyroid without carbimazole nine months later.

\section{Comment}

Amiodarone induced thyrotoxicosis was successfully treated in five patients with carbimazole alone and continuing amiodarone. The present report contrasts with previous descriptions of the ineffectiveness of carbimazole treatment in amiodarone induced thyrotoxicosis. ${ }^{13}$ The reason for this discrepancy is not clear, but it may reflect the iodine replete state of British patients, which contrasts with that of those in Tuscany and other iodine deficient areas, where carbimazole has been found to be unhelpful. ${ }^{3}$ In addition, there was evidence for pre-existing thyroid disease (goitre and positive thyroid antibodies) in only one patient, whereas other series from outside the United Kingdom included many patients with pre-existing thyroid disorders. ${ }^{3}$ We suggest that in patients presenting with amiodarone induced thyrotoxicosis, especially in areas not deficien in iodine, carbimazole alone should be the preferred treatment. Amiodarone may be continued in such patients, and long term remission of thyrotoxicosis may still result.

We are grateful to the Birmingham cardiologists for permission to report their patients.

(Gammage MD, Franklyn JA. Amiodarone and the thyroid. Quart f Mlo 1987:283:83-6

2 Mehra A, Widerhorn J, Lopresti J, Rahimteola SH. Amiodarone-induced hyperthyroidism: thyroidectomy under local anaesthesia. Am Heart $1991: 122: 1160-1$

Martino E, Aghini-Lombardi F, Mariotti S, Bartalena L, Braverman L Pinchera A Amiodarone: a common source of amiodarone-induced thyrotoxicosis. Hormome Res 1987:26:158-71.

+ Reichere LJM de Row: HA. Treatment of amiedarone induced heper thyroidism with potassium perchlorate and methimazole during amiodaron treatment. BMY 1989;298:1547-8

5 Wimpfheimer $C$, Staubli $M$, Schadelin J, Studer H. Prednisolone in amiotaron induced thyrotoxicosis. BMJ 1982;284: 1835-6.

(Accepted 29 April 1992)

\section{Department of}

Radiotherapy and

Oncology, Ninewells

Hospital and Medical

School, Dundee DD1 9SY

J A Dewar, consultant

radiotherapist and oncologist

University Department of Surgery

$\mathrm{J} M$ Horobin, research

coordinator

P E Preece, senior lecturer

R A B Wood, senior lecturer

University Department of

Cardiovascular

Epidemiology

$\mathrm{R}$ Tavendale, research fellow

$\mathrm{H}$ Tunstall-Pedoe professor

Correspondence to: $\mathrm{Mr}$ Preece.

BMf 1992;305:225-6

\section{Long term effects of tamoxifen on blood lipid values in breast cancer}

\author{
J A Dewar, J M Horobin, P E Preece, \\ R Tavendale, H Tunstall-Pedoe, R A B Wood
}

Tamoxifen is now established as adjuvant therapy in patients with operable breast cancer. 'As large numbers of women take it for many years its other metabolic effects are important..$^{2}$ A recent trial ${ }^{3+}$ has shown a lower incidence of fatal myocardial infarction in women receiving adjuvant tamoxifen. We present data on blood lipid values in a subset of patients from this trial.

\section{Patients, methods, and results}

The 44 patients studied were postmenopausal (mean age 59 years, range 45-74), had unilateral invasive breast cancer, and were included in the Scottish adjuvant tamoxifen trial ${ }^{+}$between 1980 and 1984 and followed up till 1990. Blood samples were taken preoperatively and at roughly annual intervals thereafter. Serum was stored at $-70^{\circ} \mathrm{C}$. Twenty four

Mean changes in serum cholesterol concentration in each year of follow up for treatment group compared with control group and for tamoxifen stop group compared with tamoxifen continue group

\begin{tabular}{|c|c|c|c|c|c|c|}
\hline & Year: & 1 & 2 & 3 & 4 & 5 \\
\hline Treatment group & $\begin{array}{l}\text { Mean change }(\mathrm{mmol} / \mathrm{l}) \\
\mathrm{SE} \\
\text { No of patients }\end{array}$ & $\begin{array}{r}-0.52 \\
0.34 \\
21\end{array}$ & $\begin{array}{r}-0 \cdot 96 \\
0 \cdot 21 \\
15\end{array}$ & $\begin{array}{r}-0.96 \\
0.25 \\
16\end{array}$ & $\begin{array}{r}-0 \cdot 88 \\
0 \cdot 22 \\
17\end{array}$ & $\begin{array}{r}-1 \cdot 02 \\
0 \cdot 24 \\
19\end{array}$ \\
\hline Control group & $\begin{array}{l}\text { Mean change }(\mathrm{mmol} / \mathrm{l}) \\
\text { SE } \\
\text { No of patients }\end{array}$ & $\begin{array}{r}-0 \cdot 06 \\
0 \cdot 15 \\
18\end{array}$ & $\begin{array}{r}+0 \cdot 13 \\
0 \cdot 15 \\
12\end{array}$ & $\begin{array}{r}+0.01 \\
0.25 \\
14\end{array}$ & $\begin{array}{r}-0 \cdot 01 \\
0 \cdot 20 \\
15\end{array}$ & $\begin{array}{r}+0 \cdot 27 \\
0 \cdot 21 \\
13\end{array}$ \\
\hline p Value & & 0.013 & $0 \cdot 003$ & $0 \cdot 022$ & 0.009 & 0.001 \\
\hline
\end{tabular}

\begin{tabular}{|c|c|c|c|c|}
\hline & Year: & 6 & 7 & 8 \\
\hline $\begin{array}{l}\text { Tamoxifen stop } \\
\text { group }\end{array}$ & $\begin{array}{l}\text { Mean change }(\mathrm{mmol} / \mathrm{l}) \\
\mathrm{SE} \\
\text { No of patients }\end{array}$ & $\begin{array}{c}+0 \cdot 29 \\
0 \cdot 34 \\
7\end{array}$ & $\begin{array}{r}+0 \cdot 78 \\
0 \cdot 38 \\
6\end{array}$ & $\begin{array}{c}+0 \cdot 74 \\
0 \cdot 28 \\
5\end{array}$ \\
\hline $\begin{array}{l}\text { Tamoxifen continue } \\
\text { group }\end{array}$ & $\begin{array}{l}\text { Mean change }(\mathrm{mmol} / \mathrm{l}) \\
\mathrm{SE} \\
\text { No of patients }\end{array}$ & $\begin{array}{c}-0 \cdot 10 \\
0 \cdot 17 \\
9\end{array}$ & $\begin{array}{c}+0 \cdot 17 \\
0 \cdot 20 \\
8\end{array}$ & $\begin{array}{c}-0 \cdot 39 \\
0 \cdot 22 \\
5\end{array}$ \\
\hline $\mathrm{p}$ Value & & $0 \cdot 169$ & $0 \cdot 220$ & $0 \cdot 037$ \\
\hline
\end{tabular}

patients in the treatment group received tamoxifen $20 \mathrm{mg}$ daily for five years after mastectomy or until first relapse. At five years 18 were randomised again - eight to stop tamoxifen ("tamoxifen stop" group) and 10 to continue ("tamoxifen continue" group). Twenty patients in the control group were operated on but did not receive tamoxifen.

In 1991 the samples were slowly thawed and the tota cholesterol and high density lipoprotein concentrations measured. These determinations were carried out by using an enzymatic method on a COBAS Bio analyser The precipitant used in high density lipoprotein cholesterol analysis was magnesium chloride phosphotungstic acid. Two sample comparisons were made with Mann Whitney non-parametric tests. Measurements made six months or less before any recurrence (local, distant, or contralateral) have been excluded. The mean preoperative serum cholesterol concentration in the treatment group was $6.72 \mathrm{mmol} / \mathrm{l}$ (standard error (SE) 0.22 ) and in the control group $7.03 \mathrm{mmol} / \mathrm{l}(\mathrm{SE} 0.21$ (NS).

For each patient the preoperative concentration was taken as baseline and changes from this were calculated. The mean change in cholesterol and high density lipoprotein concentrations was then calculated for each group of patients for each year of follow up. For each patient in the tamoxifen stop and tamoxifen continue groups a new baseline was calculated, being the mean value of cholesterol and high density lipoprotein for years 1-5; and subsequent changes in lipid values were compared with this. The mean changes in serum cholesterol concentration are shown in the table. No significant differences in high density lipoprotein values were observed between either the treatment and control groups or the tamoxifen stop and tamoxifen continue groups (not tabulated).

\section{Comment}

This study shows that tamoxifen consistently lower the serum cholesterol concentration and that this effect ends with cessation of treatment. No significant change in serum high density lipoprotein value was observed but, given the small numbers of patients studied, such an effect cannot entirely be excluded. The particular strengths of this study are that it comprises patients who were treated within a randomised clinical trial 